
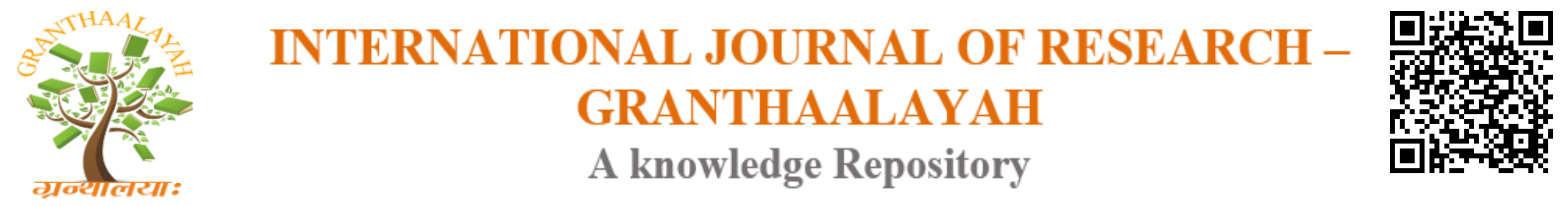

Science

\title{
AHARA VICHARA: AYURVEDIC CONCEPT OF DIET
}

\author{
Dr. Borakhade Vasundhara R. ${ }^{1}$, Dr. Rokade Reshma ${ }^{2}$ \\ ${ }^{1}$ Assistance Professor, Department of Kayachikitsa Y.A.C.P.G.T\&RC, Kodoli, Dist- Kolhapur, \\ Maharashtra, India \\ ${ }^{2}$ PG Scholar, Kayachikitsa Y.A.C.P.G.T\&RC, Kodoli, Dist- Kolhapur, Maharashtra, India
}

\begin{abstract}
Ahara is the most important factor in life. Health as well as disease is dependent on ahara. Proper diet, taken in proper manner can lead to better health or else can lead to diseases. Food is the source of life, strength, complexion and Oja of living beings. Food in turn, derives its properties from six primary tastes which are inherent in the substances that comprise food. The substances, their specific tastes, qualities, potencies and digestive transformations are responsible for equilibrium of the Dosha and Dhatu. As growth, strength, good health, complexion and the alertness of senses are traceable to food and its inequality causes illness. Diet therapy is a broad term for the practical application of the concept of nutrition as a preventive or corrective treatment of diseases. It comprises food prescribed, regulated or restricted in kind and amount for therapeutic and other purposes. This usually involves the modification of an existing dietary lifestyle to promote optimum health. However, in some cases, an alternative dietary lifestyle plan may be developed for the purpose of eliminating certain foods in order to reclaim health. Diet therapy provides an outline regarding which kind of food to eat and which to avoid. Ayurvedic principles are concerned about every part of the body, mentally and physically through diet.
\end{abstract}

Keywords: Ahara; Ahara Parinamkarak Bhava; Ahara Niyam; Vayu; Agni.

Cite This Article: Dr. Borakhade Vasundhara R., and Dr. Rokade Reshma. (2018). "AHARA VICHARA: AYURVEDIC CONCEPT OF DIET." International Journal of Research Granthaalayah, 6(2), 46-53. https://doi.org/10.5281/zenodo.1186100.

\section{Introduction}

Ahara i.e. diet is believed to be one of the Upastambha of life. Faulty diet results in disturbed functions of the body. That is the reason why while describing causative factors of diseases, dietary articles (apathya) have been given prime importance. Acharya Charak has stated that diet sustains life if taken with discipline in a proper manner. Ahara has a prime role in maintaining health and also in treating various disorders. According to Acharya Kashyap, Ahara is considered as the Mahabhaishajya i.e. the great medicine. Àyurveda emphasizes that the Àhà is the nourisher of the body elements; vital essence, vitality, complexion and other things, but its action is dependent on the proper function of Jatharagni. The Àhàra Dravyas comprising of six 
Rasas, get transformed into three kinds of Vipaka (Madhura, Amla and Katu) by the action of Jatharagni.All living beings in the universe require food. The food is said to be cause of stability for all living beings. There is nothing else except diet for sustaining the life of living beings. Complexion, clarity, good voice, longevity, astuteness, happiness, satisfaction, nourishment, strength and intellect are all conditioned by food. Diet supports the body constantly just like the house (is supported) by the pillars. Complete nutritional diet or the wholesome food is responsible for the growth of the living beings while unwholesome food for the growth of diseases. Proper growth and maintenance of the body depends on the balanced diet. Ahara and the dietetic rules are basic factors among the causes of disease. Though everyone cannot always follow all the rules due to the bindings of fast and forward life, the awareness is needed regarding the subject. Hence, it is an important part of the treatment by avoiding the causative factors of a disease.

\section{Factor those take part in the digestion}

- Ushma: Pachakagni (Digestive enzymes)

- Vata dosha / Cheshta prerak bhava (Nervous mechanism of digestion)

- Kleda / Shaithlykar bhava (Hydrolysing agent)

- Sneha / Mardavkar bhava (Softening agent)

- Kaala yoga / Samay (Time factor)

- Aharvidhi samayoga (Rules for proper digestion)

\subsection{Ushma / Jatharagni / Pachakagni : (Digestive Enzymes)}

According to Ayurveda science, our body is made up of seven basic dhatus and three doshas. To nourish that dhatus, ahar rasa is very important. Ahar rasa is produced by the ahara (food) with the help of Jatharagni.

As in the environment, the fire is used to cook the raw food to make it edible; in that same manner, the Jatharaagni which is present in the Koshtha (mahastrotasa) is helpful to convert the food in the form of the dhatu pushtikar bhava. This results in increase the Oja, bala, Varna, etc.

To maintain the balance between tridoshas, jaatharagni plays an important role. To maintain the good functioning of the body, the Jatharagni is must be conserved.

In charaka sutrasthana (27/342), Agni is said to be an important constituent of the body. Which is helpful to preserve the Prana, Oja, Aayu, Bala, Varna, Utsaha, Upachaya, Prabha and complete healthy status.

In Srimadbhagvadgita (15/14), the agni is called as the Sarvapaka, is helpful to digest all types of Dravyas (sthul and Sukshma).

\subsection{Vayu/ Vatadosha/ Cheshta prerak bhava [Nervous mechanism of digestion]}

Vata dosha is the main controller of the kinetic functions which takes place within the body. 
Vata dosha is responsible for the intake of food and to excreate the waste products which are formed during the digestive process.

The main three types of vata dosha (Prana vayu, Saman vayu, Apan vayu) takes part in the digestive system.

\subsubsection{Prana Vayu}

Oral cavity and the throat is one of the locations where prana vayu is present. The food enters in oral cavity is masticated and then entered in the oesophagus. This process of swallowing/deglutition is takes place under influence of Prana vayu. (Cha. Chi. 15/6)

Charak samhita, sharir sthan, the commentary of Chakrapani explained that vayu apakarshati vayu brought grinded food to pachakagni which helps to digest the food properly. (Su. Ni. 1/12)

Udgar: After complete digestion of the food, the air entered with the food is excreated as the udgara.

\subsubsection{Saman Vayu}

Samaan vayu increases the digestive power of the Jatharagni. That is, the samaan vayu indirectly improves the digestion (A. Hru. Su. 12/8)

By keeping food in intestine, Saman Vayu breaks it into Parthiv, Aapya, Aagneya, Vayavya, Nabhas form. (A.Hru.Su.12/8)

Prutthkaran :( separation of useful and waste products)

Because of procedure of digestion there is formation of useful and waste products. This procedure is done by Saman Vayu. Saman vayu transport the useful part i.e. annarasa to hridaya, and the remaining waste products (mutra, purish) to the lower portion of the koshtha.

Indu, Ashtang sangraha Su. 20/4:

\section{Samirano Agnehe}

Saman vayu also increase the pachana Shakti (digestive power) of the jatharagni. As in nature, the fine blow of air increases the power of fire; in the same manner, the prakruti samana vayu increases the power of the jatharagni. This function of the samana vayu is called as 'Agnisandhukshan' (stimulation of the digestive juices).

\section{Rasamutrapurishanam prathyakaranam}

After complete digestion of the food, it is divided into saara bhag (useful part) and kitta bhag (waste products). The digested useful part is called as Annarasa. The kitta bhaga is differentiated into purish and the mutra. This differentiation is depend on the functioning of the Vata dosha.

\subsubsection{Apana Vayu}

Malanam Bahi kshepta: | 
Ahara janya mala is of various types like purish, mutra, payu (dushit vayu). Apan vayu is mainly situated in the Pakvashaya, where the purisha and other malas are kept for some time before its vegakala (excretion). After the sensation of excretion, the malas are excreted through their routes of excretions.

This all process is run under influence of the Apana vayu.

\subsection{Kleda \& / Shaithilyakara Bhava: (Hydrolysing Agent)}

They ease the process of digestion and protect the seat of digestion. Such a way they are essential factor for better digestion. These factors are represented by bodhak and kledaka kapha moistens or impregnates, soften and disintegrates the ingested food and redness it too easy for the pachaka pitta to act upon them.

(Cha. Sha. 6/15) (A. Hru. Su. 12/17)

\subsection{Sneha/ Mardavkara Bhava (Softening Agent)}

mucin is also present in saliva and gastric juices. Saliva and gastric juices also contain mucin which convert the food into liquid, smooth \& soft which helps in working of jatharagni. (Ch. Sha.6/15)

\subsubsection{Kaala Yoga / Samay (Time factor)}

Time also contribute in proper digestion of eaten food. After eating food by chewing properly, it takes 1-2 hrs. to make chime in the stomach. It takes 4-5 hrs. for complete digestion of food in small intestine. After that most of the water is absorbed in large intenstine which turn the remaining part of indigested, food in thik, form which is called as pakwamala. The paka in this avastha is called as katu avsthapaka.

It take 12-14 hrs for all these process.

It means one should not have food until the eaten food is completely digested. hence, it is called 'yamadhe tu na bhoktavyavm, means one should not eat for 3 hrs. after having food. (Ch.Sh. 6/15) (Ch. Chi. 5/7)

\subsection{Samayoga}

Samayoga means Samyakyoga of Ashta Ahara Vidhi Visheshayatana. So, it indicates the importance about Visheshayatana along with Agni. Agni is proper but Visheshayatana is not maintain, it will surely lead to diseases related to Agni because Agni is disturb. When the food is taken properly and according to rules of food taking, then only the benefits of Ahara can be achieved. Any defect in diet and even in their preparation leads to ill disease. The faulty dieting habit is an etiological factor for dosha. When an individual takes different types of food articles without paying due regards toward their Prakruti, mode of preparation, combination, quantity, 
Desha, Kala, dietetic rules and wholesomeness for the individual then the Dosha get disturbed, and these dosha are responsible for all the diseases.

\section{Ahara Upyoga Niyama}

Ahara Upyoga Niyama includes the rules and regulations of diet intake. Ahara i.e diet as well as the method of diet intake both have equal importance. In other medical sciences, food and nutrition is considered important, but not the dietary habits i.e. the etiquettes to be followed for eating. It is the heritage of our ancient indian culture that can be clearly observed in Ayurvedic views. The dietetic rules can be considered as Upaya or Adravyabhuta Aushadhi for Vikaraprashamana. Ayurvedic classics have emphasized on some examination methods, rules and regulations for taking diet. Even though a man consumes wholesome diet, it is necessary to consider the following points to achieve proper digestion, assimilation and ultimately nourishment to the body. Both healthy and unhealthy person should consider these points while selecting the food.

\section{Ushnam Ashniyat}

This includes intake of warm food. Here, it is made clear that the term Ushna refers to the temperature of the food and not the ushna guna of the food. If one follows this rule and eats warm food; it tastes well, also the eaten food stimulates the digestive fire and gets digested quickly. Intake of warm food helps in vatanuloman, stimulates and secretes pitta thereby increasing agni. Extreme hot food is also not advised as it may cause mada, daha, trushna, bhrama etc. Another the food that is again made hot, after preparation which can be categorized under Paryushita Anna. The food is strictly contraindicated according to Ayurveda. Similar qualities are observed in the food that had kept for long time and then eaten. Even the working crowd, who use tiffin for convenience at their working place are unable to have warm food. Hence it is also prohibited.

\section{Snigdham Ashniyat}

This context refers to consumption of unctuous food. Here, the term Snigdha does not exactly mean Snehadravyas like ghruta, taila but also Godhuma, Shali rice etc. are advised as Snigdha. Snigdha aahar tastes well, it stimulates the digestive fire, helps in vatanuloman, due to its kledan property stimulates kledak kapha, provides firmness to the sense organs, increases strength, produces clarity of complexion.

On the contrary, extreme Snigdhata (Atisnigdha) or Asnigdha (Ruksha), both inhibit the process of digestion. Atisnigdha food is 'Guru' by property and takes more time and energy for digestion, causing Praseka, Hridayagaurava, Alasya, Aruchi, etc. On this contrary, asnigdha or ruksha food absorbs humidity of digestive tract and hampers digestion, decreases Bala and Varna, producing dryness of skin and constipation. 


\section{Laghu Ashniyat}

Laghu ahara includes both quantity \& quality of food. As per quality, meaning of word Laghu here means easy to digest. i.e which takes less time to digest. Laghu Ahara does not cause vitiation of Doshas and increase the Agni, undergoes digestion without causing any difficulty. Even the food slightly Apathya in nature do not aggravate Doshas.

\section{Jirne Viryavirudham}

One should take food only when previous meal is digested. If one takes food before the digestion of the previous meal, the digestive product of previous food, i.e immature rasa gets mixed up with the product of food taken afterwards, resulting in the provocation of all the doshas instantaneously. Also one should take food having no contradictory potencies. By taking such food one does not get afflicted with such disease as may arise from the intake of food having mutually contradictory potencies. Therefore, one should take food having no contradictory potencies.

\section{Ishta Deshe, Ishta Sarvopakaranam}

This term refers to eating in a hygienic place provided with all the necessary things for sound psychological condition during meals. One should take food in proper equipped with all the accessories and should not produce disturbing emotions like kama, krodha, chinta, bhaya etc. By following this a person does not get afflicted with such of the factors that would result to the disturbed mind.

Appropriate appliances required for dining are needed and indicated in detail by Acharyas. For specific kind of food, vessels made from specific material are mentioned in classics e.g., Ghee should be kept in vessel of Kantaloha, Fruits in Dala /Patra, Milk in Tamra (copper) vessel and Madya in vessel of Mritika etc. This specification may be due to some chemical reactions between the food material and utensils. Some materials are strictly contraindicated for specific foods e.g sour foods should not be kept in copper utensils, as the chemical reaction produces poison like substances and leads to many disorders.

\section{Na Atidrutam Ashniyat -}

The food should not be taken too hurriedly. If food is taken too hurriedly it enters the wrong passage and does not enter into the stomach properly. In this situation, one can never determine the taste of food articles and defect foreign bodies, mixed with them. Also, the food when eaten with hurry violates its normal route. The Annaja Hikka is the best example of 'Vimargagamanam'.

\section{Na Ativilambitam Ashniyat}

This concept refers to that one should not take food too slowly because this will not give satisfaction to the individual. In this situation he would take more than what is required, the food becomes cold and there will be irregularity in digestion. Therefore one should not take food very slowly. All these factors hamper Agni and the food can't be digested properly. 


\section{Ajalpan, Ahasan, Tanmana Bhunjita-}

One should not talk or laugh or be unmindful while taking food. The secretion of digestive juices gets disturbed and finally the system also gets affected which affects body as well as mind. Also one should take food in a prescribed manner, with due regard to his own self. So one should take food in a prescribed manner with due regard to his own self. The most important statement is that the food should be eaten with enough concentration towards it as well as towards the eating process. Talking and laughing divert the attention from the meals and the food is eaten too hastily or too slowly. Thus the uniform speed of eating can't be maintained; hence both the above opinions are practically true. In one meal also, some food is eaten hurriedly while some slowly if the attention is diverted by other things.

\section{Pathya}

- Go-Ghee, takra, navaneet.

- Go dugdh, aja dugdh, mahish dugdha

- Mudaga, masura, adhaki is best protein and easily digested.

- Manda, peya, vilepi, yusha

- Rakta-shali, Shashtika, Shali, Godhuma and yava are rich in carbohydrates and fiber.

- Excessive salt intake is prohibited. Here advice to use Saindhav Salt daily. Saindhav salt is best. Among all the salts because it doesn't produce side effects of salt.

- Dadima, amalaki, haritaki is Tridosha Shamaka.

- Triphala mixed with honey and ghee can be taken daily at nights to improve the strength of the eyes.

\section{Apathya}

- Dadhi, kurchika, avi dugdha, avi grita

- (Curd, Kurchika \& fish, are Kapha Prakopaka and heavy to digest)

- Alkaline foods, flours and germinated grains should not be used regularly. Alkaline foods are Pitta Prakopaka.

- Dry vegetables, uncooked Moolaka is Vata prakopaka \& germinated grains are Tridosha Prakopaka

- Fish

\section{Discussion}

Ayurveda has scientific approach in health management. The main aim of Àyurveda is to preserve the health of a healthy person and to treat the disease. The diet and regimen which is beneficial to the body and gives happiness to the mind. lots of imortannce is given to the diet with regard to its processing, quality, quantity and so on. Àhàra, Swapna (Nidra) and Brahmacarya play an important role in the maintenance of "Swasthya" of an individual. Àhàra plays an important role in healthy, diseased and convalescent states. It is more important than the medicine itself. The body can be nourished and maintained in good health status, by adopting suitable diet and full benefits of life can also be reaped by adherence to proper mental hygiene. In this era of modernization and civilization the society is conscious enough about what to eat? The awareness about the diet and their nutritional values etc. is increasing gradually, still the popularity of fast food / junk food is greater due to the fast life. According to Ayurveda this can be classified as "Pradnyaparadha'. People basically know very little about them and they who 
know are less bothered to obey such rules, even they do not have trust enough to consider the code of diet as an important health matter. The proper use of diet not only prevents the disease but play major role in the management of the disease. It is possible if one uses diet considering the prakriti, tridosha, satmya asatmya of person as well as panchabhautik composition of dietary substance. The dietetic field is one such most important field of life. These are the dietetic regulations and procedure for those, who are healthy as well as for certain types of patients. Wholesome diet is prime cause for the growth and development of the body, on the contrary, unwholesome diet causes several diseases. Acharya charaka stated that the ideal diet is that, which rebuilds the worn-out systems, nourishes dhàtus and maintains equilibrium of the body constituents. Irrational diet acts otherwise, producing disease. One should eat food, which is hot, unctuous, in due measure, after the digestion of previous food, and nonantagonistic in potency. It should be eaten in a hygienic place, provided with all accessories, neither too hurriedly, nor too leisurely, without talking or laughing with full concentration and having proper regard to oneself. Also Fuel like coal is required to keep the fire continuously or enlighten. Similarly, the Àhàra acts as the Indhana (fuel) for the Jatharagni and other Agnis in the body. Àhàra alone sustains the properties of Agni in the body. This shows the mutual relationship of Àhàra and Agni. If the food is not taken at all or in less quantity, due to the lack of Indhana, the Agni starts digesting the Dhàtus of the body and these Dhàtus get depleted and the Doşas become aggravated, resulting in the diseases.

\section{References}

[1] Vd.Brahmanand Tripathi, Charak Samhita vol 1 \& vol 2, Chaukhamba prakashana, Hindi, reprint 2014.

[2] Vd. Ambikadatta Shastri, Sushrut samhita vol 2, Chaukahmba prakashana, Hindi, reprint 2013.

[3] Vd. Shivprasad shrama, Ashtang sangrah, Chaukahmba prakashana, Hindi, reprint 2008.

[4] Vd. Brahmanand Tripathi, Ashtang Hridayam, Chaukhamba prakashana, Hindi, reprint 2009.

[5] Vd. Priyavat Shrama, Dravyaguna viganyan, Chaukhamba prakashana, Hindi, reprint 1999

*Corresponding author.

E-mail address: reshmarokade17@ gmail.com 